\title{
Critical Limits of Phosphorus in Relation to the Growth and Dry Matter Yield of French Bean (Phaseolus vulgaris L.) in Acid Soils of Thoubal District, Manipur (India)
}

\author{
Herojit Singh Athokpam*, Rabichandra Khangembam, Nandini Chongtham, \\ K. Nandini Devi, Naorem Brajendra Singh, Athokpam Sanatomba, \\ Naorem Gopimohan Singh and P.T. Sharma
}

College of Agriculture, Central Agricultural University, Imphal-795004, India

*Corresponding author

\section{A B S T R A C T}

\begin{tabular}{l} 
K e y w or d s \\
$\begin{array}{l}\text { Acidic soils, Dry matter, } \\
\text { P uptake, French bean, } \\
\text { Critical P concentration, } \\
\text { Bray's per cent yield }\end{array}$ \\
\hline Article Info \\
$\begin{array}{l}\text { Accepted: } \\
\text { 12 September } 2018 \\
\text { Available Online: } \\
\text { 10 October } 2018\end{array}$ \\
\hline
\end{tabular}

\section{Introduction}

Phosphorus has been called the key to life because it is directly involved in most life process. It is component of every living cell and tends to be concentrated in seeds and in the growing point of plants. Phosphorus is the backbone of fertilization in Indian agriculture.

At present, 5 per cent of Indian soil have adequate available phosphorus, 49.3 per cent are under low category, 48.8 per cent medium and 1.9 per cent high category (Sureshkumar,
1999). Information of phosphorus fertility status of soils is of great importance to determine the level of phosphorus fertilizers to be applied to the crops.

Plants appear to face severe problems in getting phosphorus at early stage in their development. So, phosphorus deficiency symptoms most often occur in seedlings and young plants. Phosphorus is mobile within the plants and its translocation is from the older tissue to the growing points. This causes the deficiency symptoms appeared on the lower 
leaves. Deficiency of phosphorus causes stunted growth, dark green colour associated with purplish colour in the seedling stage. Inadequate supply of phosphate generally cause delay in crop maturity and seed formation.

Of all the beans, French bean is most extensively grown as green vegetable. In India, nearly 6000 hectares annually produce 12, 50,000 tonnes of bean. Dry and green beans rank high as a cheap source of nourishing food. They are a valuable source of protein, calcium, iron and vitamins (Choudhury, 2006). In recent years, the cultivation of French bean (Phaseolus vulgaris L.), cv. Contender has picked up in Manipur.

Among several agro-techniques, adequate and balanced nutrition plays an important role increasing yield. Correlating nutrients content and their ratio in plant parts during crop growth with yield and yield attributes is prerequisite to find out critical nutrients for optimum yield and quality of crop. Nutrient deficiency of plant can be replenished well in advance before heavy yield losses. However, there is no such work in Manipur and hence, the present investigation was designed to study the response of French bean to phosphorus fertilization in acidic soils and evaluate the critical limits of phosphorus in soils and plant.

\section{Materials and Methods}

Twenty surface soil samples $(0-15 \mathrm{~cm})$ were collected from different locations of the cultivated fields of Thoubal District, Manipur. The air-dried soil samples were ground in wooden mortar and pestle and passed through $2 \mathrm{~mm}$ sieve. The mechanical analysis of the soils is determined by hydrometer method (Bouyoucos, 1951). These samples were analyzed for $\mathrm{pH}, \mathrm{EC}, \mathrm{P}_{2} \mathrm{O}_{5}$, and $\mathrm{K}_{2} \mathrm{O}$ using standard procedures as described by Jackson
(1973), available N (Subbiah and Asija, 1956) and CEC as described by Borah et al., (1987), exchangeable $\mathrm{Ca}$ and $\mathrm{Mg}$ (Chopra and Kanwar, 1976). Organic carbon was determined by wet oxidation method of Walkley and Black (1934). Available P was determined using Bray $\mathrm{P}_{1}$ and Bray $\mathrm{P}_{2}$ (Bray and Kurtz, 1945), Olsen P (Olsen et al., 1954), Truog P (Truog, 1930), Morgan P (Morgan, 1937) and Mehlich $P_{1}$ (Mehlich, 1937).

Three $\mathrm{kg}$ of soil were filled in pots and phosphorus were applied $0,60,80 \mathrm{~kg} \mathrm{P}_{2} \mathrm{O}_{5}$ ha $^{-}$ 1 through single super phosphate. The treatments were replicated thrice in completely randomized design. A basal dose of $\mathrm{N}$ and $\mathrm{K}_{2} \mathrm{O} @ 50$ : $60 \mathrm{~N}$ : $\mathrm{K}_{2} \mathrm{O} \mathrm{ha}^{-1}$ in the form of urea and muriate of potash in each pot. French bean cv. Contender were sown and thinned to three plants in each pot after 7 days. The moisture level was maintained at field capacity level in all the pots by irrigating with distilled water as and when required. The crop was harvested 40 days of growing. The plant samples were washed to remove dirt and then oven dried at $65^{\circ} \mathrm{C}$ for 48 hours and the dry matter yield was recorded. The samples were ground and powdered samples were analyzed for nitrogen by macrokjeldahl method, phosphorus by tri-acid mixture $\left(\mathrm{HNO}_{3}: \mathrm{HClO}_{4}: \mathrm{H}_{2} \mathrm{SO}_{4}\right)$ digestion and using vanadomolybdophosphoric acid yellow colour method by spectrophotometry and plant potassium by flame photometry method (Jackson, 1973). The critical limits of soil and plant were determined by technique of Cate and Nelson (1965). Bray's per cent yield and uptake of French bean was calculated as:

Yield without fertilizer

Bray's per cent yield = --------------- x100

Maximum yield in fertilizer treated pots

Uptake without fertilizer

Bray's per cent uptake = ------------ x 100

Maximum uptake in fertilizer treated pots 


\section{Results and Discussion}

The initial physico-chemical properties of the soils of the Thoubal district of Manipur are presented in Table 1. The soil texture varied from sandy clay loam, clay loam, silty clay and clay in textural class.

All the soil samples are acidic i.e. soil $\mathrm{pH}$ varied from 4.61 to 6.26 with mean value of 5.48, EC ranged from 0.12 to $0.33 \mathrm{dSm}^{-1}$ at $25^{\circ} \mathrm{C}$, CEC varied from 9.21 to 35.71 $\left[\mathrm{cmol}\left(\mathrm{p}^{+}\right) \mathrm{kg}^{-1}\right], \mathrm{Ca}$ content ranged from 1.54 to $5.45\left[\mathrm{cmol}\left(\mathrm{p}^{+}\right) \mathrm{kg}^{-1}\right]$, and $\mathrm{Mg}$ content varied from 1.45 to $5.35\left[\mathrm{cmol}\left(\mathrm{p}^{+}\right) \mathrm{kg}^{-1}\right]$. Organic carbon content of the soils are high, it ranged from 9.9 to $24.1 \mathrm{~g} \mathrm{~kg}^{-1}$ and total $\mathrm{N}$ content of the soils varied from 0.1 to 0.4 per cent with a mean value of 0.25 per cent.

The available $\mathrm{N}$ and $\mathrm{K}$ content of soils collected from various locations ranged from 246.21 to $408.38 \mathrm{~kg} \mathrm{ha}^{-1}$ and 162.61 to 264.99 $\mathrm{kg} \mathrm{ha}^{-1}$, respectively.

\section{Dry matter yield}

The dry matter yield of French bean cv. Contender was affected with application of phosphatic fertilizer regardless of the initial soil properties. Dry matter yield of the control pot varied from 1.91 to $5.19 \mathrm{~g} / \mathrm{pot}$ as compared with 3.59 to $5.40 \mathrm{~g} / \mathrm{pot}$ in $60 \mathrm{~kg}$ $\mathrm{P}_{2} \mathrm{O}_{5} \mathrm{ha}^{-1}$ and 3.37 to $5.31 \mathrm{~g} /$ pot in $80 \mathrm{~kg} \mathrm{P}_{2} \mathrm{O}_{5}$ ha $^{-1}$ (Table 2).

Application of $60 \mathrm{~kg} \mathrm{P}_{2} \mathrm{O}_{5} \mathrm{ha}^{-1}$ results in highest dry matter production significantly. The increased dry matter production due to phosphorus fertilization might be due increase plant height, number of branches, number of leaves and leave area of the plant. Similar observations were also reported by Abbas et al., (1994a and 1994b), Patel and Chandravanshi (1996), Hussain, et al., (2001) and Kakon et al., (2016).
Nitrogen, phosphorus and potassium uptake

The nitrogen, phosphorus and potassium uptake by the plant was highest with the treatment of $60 \mathrm{~kg} \mathrm{P}_{2} \mathrm{O}_{5} \mathrm{ha}^{-1}$ (Table 4) which is significantly superior to the other treatments. The uptake of these nutrients by the plant is combined effect of higher nutrient concentration in the plant and higher dry matter production.

A luxuriant vegetative growth and higher dry matter accumulation with the phosphatic fertilization might increase the nutrients uptake by the plant. Similar results were also reported by Reddy et al., (1990), Bhalu et al., (1995) and Palb (2015).

\section{Correlation}

All the six $\mathrm{P}$ extractants used showed the positive and significant correlation with Bray's per cent yield of French bean cv. Contender with varying degree. Among the $\mathrm{P}$ extractant used, Bray $\mathrm{P}_{1}$ showed higher degree of correlation with Bray's per cent yield $(\mathrm{r}=$ $\left.0.679^{* *}\right)$, Bray's per cent uptake $\left(\mathrm{r}=0.629^{* *}\right)$, Dry matter yield $\left(\mathrm{r}=0.702^{* *}\right), \mathrm{P}$ content $\left(\mathrm{r}=0.578^{*}\right)$ and total $\mathrm{P}$ uptake $\left(\mathrm{r}=0.688^{* *}\right)$ compared to the other extractants used (Table $3)$. Therefore, Bray $P_{1}$ must be used as $P$ extractant for growing French bean plant cv. Contender in acid soils of Manipur for profitable yield.

\section{Critical limit of $\mathbf{P}$ in soil}

The critical limit of phosphorus in soils for growing of French bean cv. Contender varied with method of phosphorus extraction. Base on the graphical procedure of Cate and Nelson (1965), the critical limit of soils varied from 10.0 to $23.6 \mathrm{~kg} \mathrm{P}_{2} \mathrm{O}_{5} \mathrm{ha}^{-1}$. However, Bray $\mathrm{P}_{1}$ showed the higher degree of correlation with the plant parameters than the other extractants (Fig. 2-7). 
Table.1 Some physio - chemical properties of the soil

\begin{tabular}{|c|c|c|c|c|c|c|c|c|c|c|c|c|}
\hline & pH & EC & $\mathrm{OC}$ & $\begin{array}{c}\text { Total } \\
\mathbf{N}\end{array}$ & $\mathbf{A v} \mathbf{N}$ & Av K & $\mathrm{Ca}$ & Mg & CEC & & Texture & \\
\hline $\begin{array}{c}\text { Soil } \\
\text { sample } \\
\end{array}$ & & $(\mathrm{dS} / \mathrm{m}-1)$ & $\mathrm{g} \mathrm{kg}^{-1}$ & $\%$ & $\left(\mathrm{kgha}^{-1}\right)$ & $\left(\mathrm{kgha}^{-1}\right)$ & {$\left[\mathrm{cmol}(\mathrm{p}+) \mathrm{kg}^{-1}\right]$} & {$\left[\mathrm{cmol}(\mathrm{p}+) \mathrm{kg}^{-1}\right]$} & {$\left[\mathrm{cmol}(\mathrm{p}+) \mathrm{kg}^{-1}\right]$} & Sand $\%$ & Silt\% & Clay \% \\
\hline 1 & 5.21 & 0.13 & 14.3 & 0.19 & 246.21 & 215.88 & 2.13 & 1.99 & 11.10 & 45.93 & 19.27 & 34.80 \\
\hline 2 & 4.77 & 0.17 & 11.1 & 0.35 & 305.18 & 221.63 & 2.63 & 2.49 & 12.48 & 31.67 & 24.96 & 43.37 \\
\hline 3 & 5.17 & 0.24 & 17.1 & 0.20 & 389.08 & 193.24 & 2.35 & 2.22 & 14.94 & 39.87 & 25.30 & 34.83 \\
\hline 4 & 5.94 & 0.18 & 19.6 & 0.27 & 342.60 & 227.63 & 2.62 & 2.24 & 31.34 & 26.22 & 29.37 & 44.42 \\
\hline 5 & 5.47 & 0.20 & 20.2 & 0.38 & 352.98 & 206.34 & 3.56 & 3.47 & 30.25 & 16.06 & 24.08 & 59.86 \\
\hline$\overline{6}$ & 5.01 & 0.15 & 15.1 & 0.16 & 333.16 & 184.59 & 2.35 & 2.24 & 16.32 & 43.85 & 28.56 & 27.59 \\
\hline 7 & 4.61 & 0.12 & 10.0 & 0.10 & 250.85 & 238.65 & 1.54 & 1.45 & 9.21 & 63.11 & 12.12 & 24.78 \\
\hline 8 & 5.47 & 0.13 & 09.9 & 0.28 & 272.98 & 203.68 & 1.88 & 1.87 & 18.76 & 21.72 & 23.26 & 55.02 \\
\hline 9 & 5.60 & 0.17 & 18.5 & 0.27 & 285.41 & 197.49 & 3.46 & 3.44 & 26.28 & 19.43 & 20.18 & 60.38 \\
\hline 10 & 5.95 & 0.24 & 12.4 & 0.36 & 305.59 & 214.50 & 1.82 & 1.74 & 18.44 & 10.54 & 18.97 & 70.49 \\
\hline 11 & 5.41 & 0.22 & 20.2 & 0.12 & 267.20 & 227.21 & 4.30 & 4.23 & 20.35 & 33.93 & 12.71 & 53.35 \\
\hline 12 & 5.51 & 0.21 & 19.5 & 0.29 & 382.23 & 221.21 & 4.96 & 4.76 & 23.39 & 16.65 & 29.18 & 54.17 \\
\hline 13 & 5.29 & 0.14 & 13.4 & 0.20 & 372.14 & 200.26 & 2.04 & 1.90 & 17.48 & 7.31 & 19.31 & 73.38 \\
\hline 14 & 5.84 & 0.16 & 17.2 & 0.35 & 366.39 & 209.05 & 4.71 & 4.54 & 22.51 & 24.67 & 34.79 & 41.14 \\
\hline 15 & 6.26 & 0.33 & 24.1 & 0.40 & 408.38 & 264.99 & 5.45 & 5.35 & 35.71 & 4.45 & 22.49 & 73.07 \\
\hline 16 & 5.79 & 0.25 & 22.1 & 0.25 & 365.56 & 163.85 & 5.07 & 4.97 & 14.45 & 7.02 & 21.07 & 71.90 \\
\hline 17 & 6.09 & 0.14 & 11.7 & 0.25 & 308.82 & 236.45 & 2.24 & 2.14 & 13.26 & 24.15 & 14.85 & 61.00 \\
\hline 18 & 5.11 & 0.16 & 21.4 & 0.27 & 353.58 & 248.97 & 4.14 & 4.08 & 26.61 & 7.29 & 48.14 & 44.57 \\
\hline 19 & 5.33 & 0.15 & 21.7 & 0.31 & 309.15 & 176.15 & 2.47 & 2.49 & 13.82 & 34.56 & 30.61 & 34.84 \\
\hline 20 & 5.82 & 0.29 & 09.9 & 0.15 & 297.80 & 162.61 & 5.06 & 4.94 & 9.87 & 11.93 & 27.65 & 60.42 \\
\hline Mean & 5.48 & 0.19 & 16.5 & 0.25 & 325.76 & 210.75 & 3.24 & 3.14 & 19.33 & 24.49 & 24.34 & 51.17 \\
\hline
\end{tabular}


Table.2 Effect of phosphorus application on dry matter yield, phosphorus concentration and its uptake by French bean

\begin{tabular}{|c|c|c|c|c|c|c|c|c|c|c|c|c|}
\hline \multirow[t]{2}{*}{$\begin{array}{l}\text { Soil } \\
\text { sample }\end{array}$} & \multirow{2}{*}{$\begin{array}{l}\text { Bray 's } \\
\text { extractable } \\
\mathrm{P}(\mathrm{ppm})\end{array}$} & \multicolumn{3}{|c|}{$\begin{array}{l}\text { Dry matter yield (g/pot) } \\
\mathrm{P}_{2} \mathrm{O}_{5} \text { level }\left(\mathrm{kg} \mathrm{ha}^{-1}\right)\end{array}$} & \multirow[t]{2}{*}{ Mean } & \multirow{2}{*}{$\begin{array}{c}\text { Bray's \% } \\
\text { P } \\
\text { Yield }\end{array}$} & \multirow{2}{*}{$\begin{array}{c}\mathrm{P} \\
\text { concentration } \\
\text { in plants of no } \\
\mathrm{P} \\
\text { Pots }(\%)\end{array}$} & \multicolumn{3}{|c|}{$\begin{array}{l}\text { P uptake by uptake }(\mathrm{mg} / \mathrm{pot}) \\
\mathrm{P}_{2} \mathrm{O}_{5} \text { level }\left(\mathrm{kg} \mathrm{ha}^{-1}\right)\end{array}$} & \multirow[t]{2}{*}{ Mean } & \multirow{2}{*}{$\begin{array}{c}\text { Bray's } \\
\% \text { P } \\
\text { Uptake }\end{array}$} \\
\hline & & 0 & 60 & 80 & & & & 0 & 60 & 80 & & \\
\hline 1 & 7.61 & 2.33 & 4.46 & 4.44 & 3.75 & 52.34 & 0.23 & 5.26 & 10.17 & 10.05 & 8.49 & 51.77 \\
\hline 2 & 19.55 & 3.89 & 5.12 & 4.93 & 4.65 & 75.93 & 0.28 & 10.71 & 14.25 & 13.36 & 12.77 & 75.14 \\
\hline 3 & 22.60 & 4.85 & 5.22 & 4.87 & 4.98 & 92.98 & 0.32 & 15.32 & 17.09 & 14.93 & 15.78 & 89.63 \\
\hline 4 & 20.14 & 2.01 & 4.14 & 4.09 & 3.41 & 48.57 & 0.33 & 6.63 & 14.75 & 12.62 & 11.34 & 44.97 \\
\hline 5 & 16.14 & 3.28 & 3.59 & 3.58 & 3.49 & 91.38 & 0.38 & 12.50 & 13.71 & 13.02 & 13.07 & 91.18 \\
\hline 6 & 19.83 & 3.49 & 3.82 & 3.62 & 3.64 & 91.23 & 0.23 & 8.03 & 8.97 & 8.34 & 8.44 & 89.51 \\
\hline 7 & 4.53 & 1.91 & 4.28 & 5.27 & 3.82 & 44.70 & 0.18 & 3.48 & 7.89 & 10.19 & 7.19 & 44.11 \\
\hline 8 & 16.59 & 4.14 & 4.75 & 4.57 & 4.48 & 87.23 & 0.26 & 10.87 & 11.71 & 10.70 & 11.09 & 92.77 \\
\hline 9 & 20.38 & 3.36 & 4.77 & 4.52 & 4.22 & 70.35 & 0.26 & 8.60 & 11.77 & 11.95 & 10.78 & 73.07 \\
\hline 10 & 21.64 & 3.70 & 4.13 & 4.89 & 4.24 & 89.66 & 0.30 & 11.24 & 12.55 & 13.82 & 12.54 & 89.57 \\
\hline 11 & 20.89 & 3.05 & 4.38 & 4.34 & 3.92 & 69.53 & 0.20 & 6.14 & 8.87 & 8.09 & 7.70 & 69.21 \\
\hline 12 & 15.94 & 4.11 & 5.23 & 5.17 & 4.84 & 78.73 & 0.40 & 16.54 & 21.23 & 20.73 & 19.50 & 77.87 \\
\hline 13 & 16.64 & 2.46 & 3.71 & 3.37 & 3.18 & 66.27 & 0.24 & 5.80 & 8.84 & 8.46 & 7.70 & 65.58 \\
\hline 14 & 21.37 & 3.06 & 4.41 & 4.04 & 3.84 & 69.39 & 0.35 & 10.56 & 15.79 & 13.84 & 13.40 & 66.89 \\
\hline 15 & 31.12 & 5.19 & 5.40 & 5.31 & 5.30 & 96.21 & 0.45 & 23.21 & 26.05 & 23.39 & 24.21 & 89.09 \\
\hline 16 & 27.49 & 4.09 & 4.34 & 4.14 & 4.19 & 94.36 & 0.35 & 14.34 & 15.23 & 13.99 & 14.52 & 94.15 \\
\hline 17 & 12.95 & 1.98 & 4.32 & 4.29 & 3.53 & 45.78 & 0.20 & 3.96 & 8.82 & 7.99 & 6.92 & 44.91 \\
\hline 18 & 19.70 & 3.87 & 5.30 & 4.26 & 4.48 & 72.93 & 0.29 & 11.32 & 15.74 & 11.09 & 12.72 & 71.96 \\
\hline 19 & 20.85 & 3.37 & 5.04 & 5.00 & 4.47 & 66.86 & 0.23 & 7.78 & 10.95 & 10.23 & 9.65 & 71.10 \\
\hline 20 & 17.77 & 3.34 & 4.80 & 4.50 & 4.21 & 69.49 & 0.19 & 6.50 & 9.01 & 8.96 & 8.15 & 72.18 \\
\hline Mean & & 3.37 & 4.56 & 4.46 & 4.13 & 73.70 & 0.28 & 9.94 & 13.17 & 12.29 & 11.80 & 73.23 \\
\hline $\begin{array}{l}\mathrm{CD} \text { at } 5^{\circ} \\
\mathrm{CD} \text { at } 5^{\circ} \\
\mathrm{CD} \text { at } 5^{\circ}\end{array}$ & 7 for P level & $\begin{array}{l}\text { ean }=0 \\
=0.1 \\
\text { nean }=\end{array}$ & 936 & & & & & & & & & \\
\hline
\end{tabular}


Table.3 Simple correlation coefficient between different extractants and yield parameters of French bean

\begin{tabular}{|l|c|c|c|c|c|}
\hline \multicolumn{1}{|c|}{ Extractant } & $\begin{array}{c}\text { Dry Matter yield } \\
\text { (control) }\end{array}$ & $\begin{array}{c}\text { P content } \\
\text { (control) }\end{array}$ & $\begin{array}{c}\text { Total P uptake } \\
\text { (control) }\end{array}$ & $\begin{array}{c}\text { Bray's\% } \\
\text { yield }\end{array}$ \\
\hline Bray P1 & $0.702^{* *}$ & $0.578^{*}$ & $0.688^{* *}$ & $0.679 * *$ \\
\hline uray P2 & $0.524^{*}$ & $0.486^{*}$ & $0.553^{*}$ & $0.629 * *$ \\
\hline Olsen-P & $0.450^{*}$ & 0.431 & $0.510^{*}$ & 0.416 \\
\hline Mehlich-P & $0.479 *$ & $0.499^{*}$ & $0.512^{*}$ & $0.443^{*}$ & 0.405 \\
\hline Truog-P & 0.441 & 0.406 & $0.513 *$ & $0.526^{*}$ & $0.480^{*}$ \\
\hline Morgan-P & 0.428 & 0.445 & $0.452^{*}$ & $0.410^{*}$ & 0.362 \\
\hline
\end{tabular}

Table.4 Effect of Phosphorus application on nitrogen, phosphorus and potassium uptake by French bean

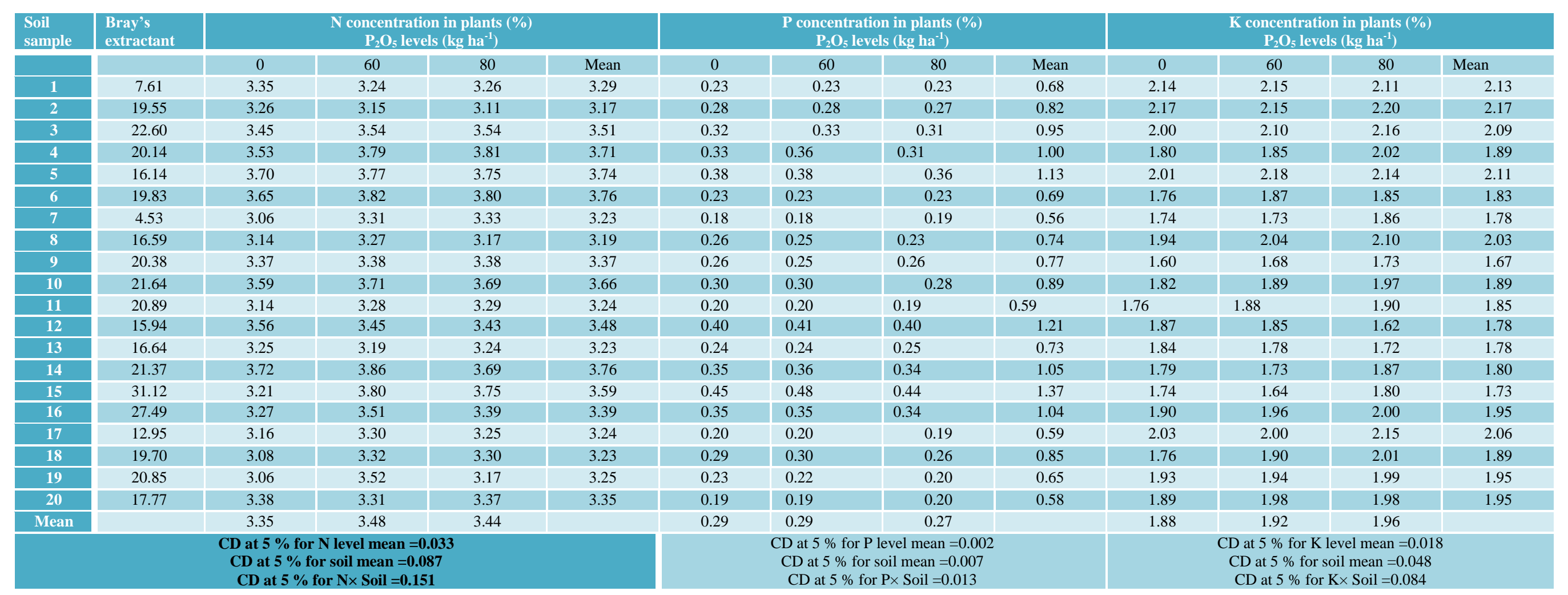


Fig.1 Relationship between the soil phosphorus and relatively yield of French bean

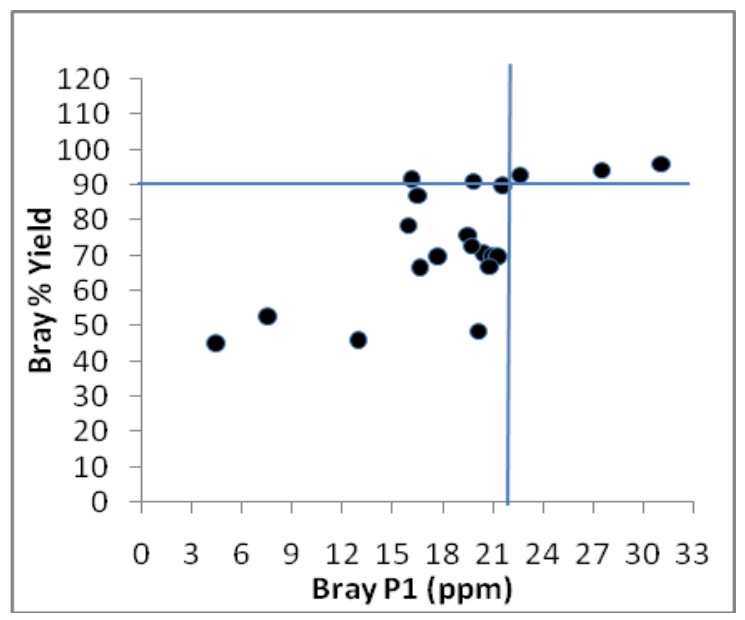

Fig.2 Relationship between the soil phosphorus and relatively yield of French bean

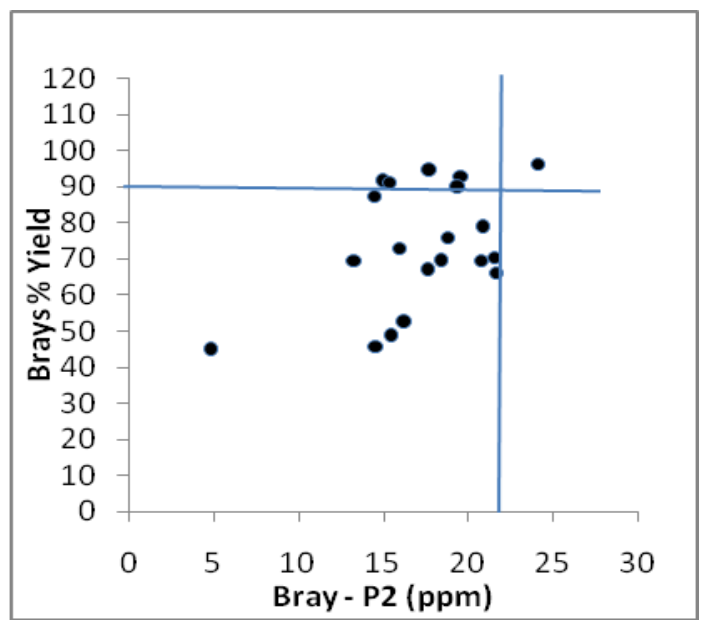

Fig.3 Relationship between the soil phosphorus and relatively yield of French bean

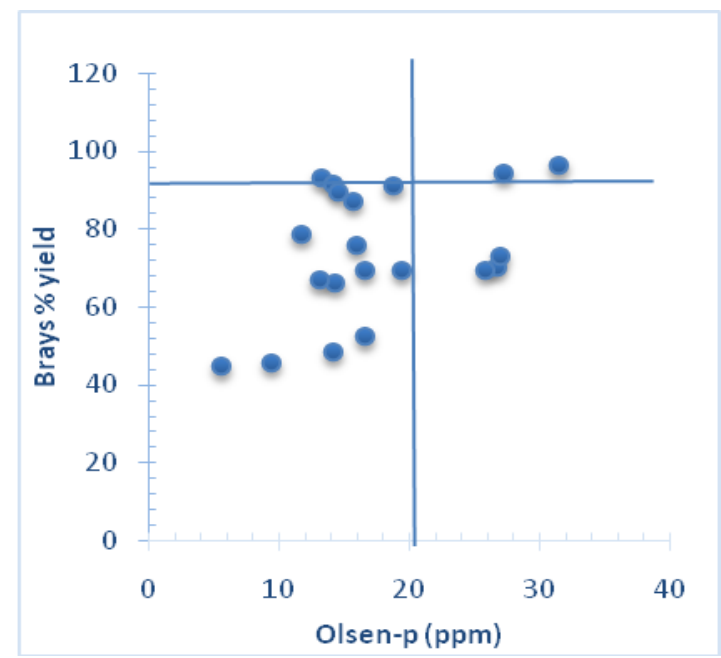


Fig.4 Relationship between the soil phosphorus and relatively yield of French bean

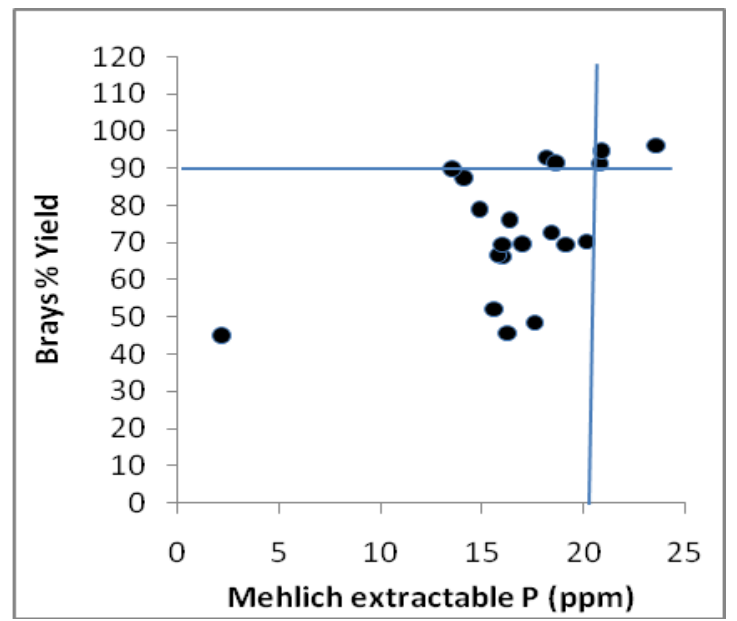

Fig.5 Relationship between the soil phosphorus and relatively yield of French bean

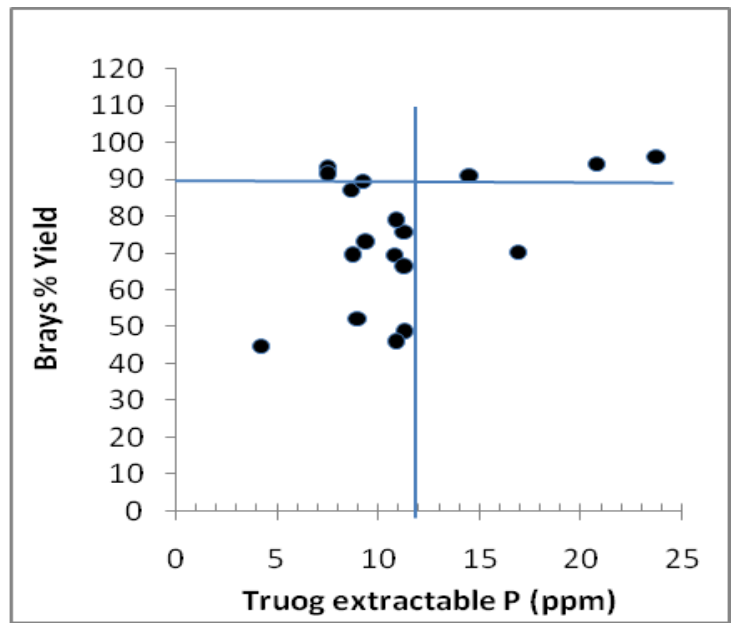

Fig.6 Relationship between the soil phosphorus and relatively yield of French bean

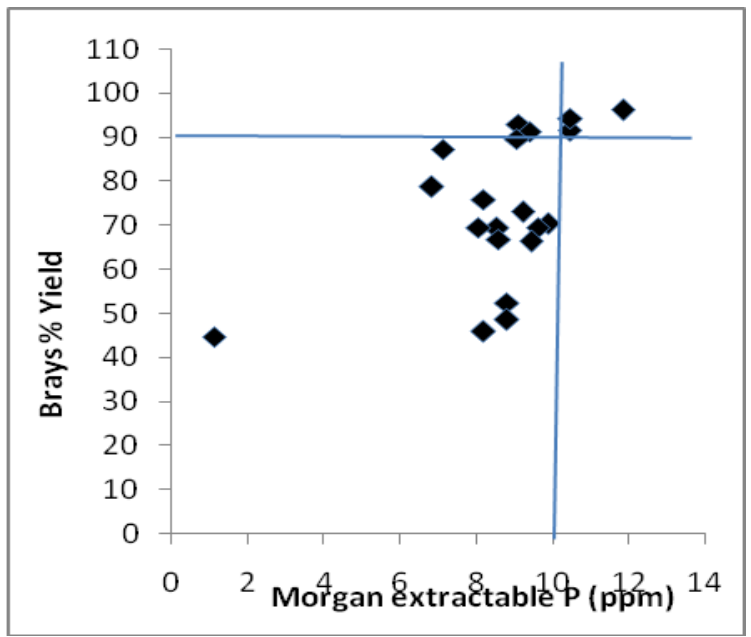


Fig.7 Relationship between the plant P concentration and relatively yield of French bean

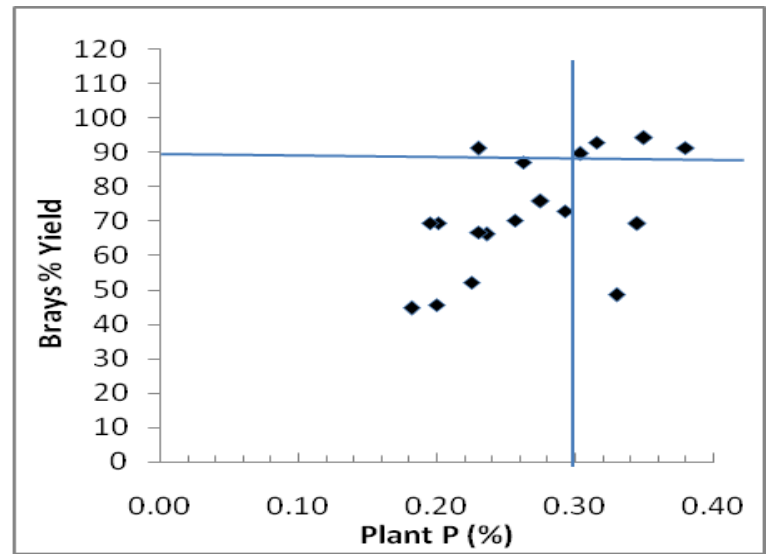

Thus, $21.2 \mathrm{~kg} \mathrm{P}_{2} \mathrm{O}_{5}$ ha $^{-1}$ (Fig. 1) is the critical limit of available phosphorus in these soils for demarcating the phosphorus responsive soil from the unresponsive soil ones. A soil was to be considered as nonresponsive to phosphorus application where Bray's per cent dry matter was more than 90 . All the soil testing below $21.2 \mathrm{~kg} \mathrm{P}_{2} \mathrm{O}_{5} \mathrm{ha}^{-1}$ by this method may be responded to phosphorus application for French bean growing.

\section{Critical limit of $\mathbf{P}$ in plant}

The critical limit of phosphorus concentration in French bean plant was also estimated using Cate and Nelson (1965) technique. A value of 0.29 per cent could distinguish the phosphorus deficient plants from those of sufficient ones (Fig. 7), partitioning the two dimensional percentage yield versus phosphorus content in 40 days old French bean cv. Contender plant scattered into two group. Thus, the present study lays emphasis on phosphorus fertilization on French bean on the basis of critical values in the soils and plant.

\section{References}

Abbas, Md., Singh, M.P., Nigam, K.P. and Kandalkar. 1994a. Effect of phosphorus on plant densities and plant type on different growth and physiological parameters of soybean (Glycine max). Indian Journal of Agronomy. 39(2): 246-248.

Abbas, Md., singh, M.P., Nigam, K.P. and Kandalkar. 1994b. Effect of phosphorus on plant densities and plant type on yield attributing characters of soybean (Glycine max). Indian Journal of Agronomy. 39(2): 249-251.

Bhalu, V.B., Sadaria, S.G., Kaneria, B.B. and Khanpara, V.D. 1995. Effect of nitrogen, phosphorus and Rhizobium inoculation on yield and quality, $\mathrm{N}$ and $\mathrm{p}$ uptake and economics of blackgram. Indian Journal of agronomy. 40: 316318.

Borah, D.K., Bordoloi, P.K., Karmakar, R.M., Baruah, N.G. and Das, M. 1987. Practical Manual of Fundamental of Soil Science (Part-III), Jorhat, Assam.

Bouyoucos, G.J. 1951. Soil Science. 23: 319343.

Bray, R.H. and Kurtz, L.T. 1945. Determination of total, organic and available forms of phosphate in soils. Soil Science. 59: 39-45.

Cate, R.B. and Nelson, L.A. 1965. Graphical procedure for critical limits of nutrients. Proceedings of Soil Science Society of America. 89: 658. 
Chopra, S.L. and Kanwar, J. 1976. Analytical agricultural Chemistry. Kalayani Publisher. Ludhiana, New Delhi.

Choudhury, B. 2006. Vegetables. National Book trust of India. A-5 Green Park, New Delhi.

Hussain, N., Mehdi, M. and Kant, R.H. 2001. Response of nitrogen and phosphorus on growth and yield attributes of blackgram (Vigna mungo). Research Journal of agricultural Sciences.2: 334336.

Jackson, M.L. 1973. Soil Chemical Analysis, Prentice Hall of India Pvt. Ltd., New Delhi.

Kakon, S.S., Bhuiya, M.S.U. and Hossain, S.M.A. 2016. Effectn of nitrogen and phosphorus on growth and seed yield of French bean. Bangladesh Journal of agricultural Research. 41: 759-772.

Mehlich, A. 1978. New extractant for soil test evaluation of phosphorus, potassium, magnesium, calcium, sodium, manganese and zinc. Communication in Soil Science and plant analysis. 15: 1409-1416.

Morgan, M.H. 1937. The Universal soil Testing System, Bulletin 392. Connecticut Agricultural Experimental Station, New Haven.

Olsen, S.R., Cole, C.V. and Watanabe, F.S. 1954. Estimation of available phosphorus in soils by extraction with sodium bicarbonate.Crc.No.939, pp.19, US Department of agriculture, Washington DC.
Palb, J.B.S. 2015. Standardization of optimum requirement of nitrogen, phosphorus and potassium for pole bean (Phaseolus vulgaris L.). M.Sc. (Agri) in Horticulture Thesis submitted to University of Agricultural Sciences, Bengaluru.

Patel, S.P. and Chandravanshi, B.R. 1996. Nitrogen and phosphorus nutrients of soybean (Glycine max) grown in vertisol. Indian Journal of agronomy. 41(4): 601-603.

Reddy, T.R., Rao, M. and Rao, K.R. (1990). Response of soybean (Glycine max L. Meril) to nitrogen and phosphorus. Indian Journal of Agronomy. 35(3): 308-301.

Subbiah, B.V. and Asija, G.L. 1956. A rapid procedure for estimation of available $\mathrm{N}$ in soils. Current Science. 25: 259-260.

Sureshkumar, P. 1999. Final report of ICAR adhoc scheme on variability in iron and zinc availability in the laterite and lateritic soils of central Kerala with reference to rice nutrition. Radiotracer laboratory, College of Horticulture, Kerala Agricultural University, Trissur.

Truog, E. 1930. Determination of readily available phosphorus of soil. Journal of American Society of Agronomy.22: 874-882.

Walkley, A. and Black, I.A. 1934. An examination of the Degtjareff method determining soil organic matter and a proposed modification of the chromic acid titration method. Soil Science. 34: 29-38.

\section{How to cite this article:}

Herojit Singh Athokpam, Rabichandra Khangembam, Nandini Chongtham, K. Nandini Devi, Naorem Brajendra Singh, Athokpam Sanatomba, Naorem Gopimohan Singh and Sharma, P.T. 2018. Critical Limits of Phosphorus in Relation to the Growth and Dry Matter Yield of French Bean (Phaseolus vulgaris L.) in Acid Soils of Thoubal District, Manipur (India). Int.J.Curr.Microbiol.App.Sci. 7(10): 1435-1444. doi: https://doi.org/10.20546/ijcmas.2018.710.159 